\title{
Can European Productivity Make Progress?
}

Since the Lisbon European Council in 2000, the European Union has been working to improve its industrial and innovation policy, with the aim of turning the European economy into the most competitive and dynamic knowledge-based economic system in the world. Its

Davide Castellani, Henley Business School, University of Reading, UK.

Mariacristina Piva, Università Cattolica del Sacro Cuore, Piacenza, Italy.

Torben Schubert, Lund University, Sweden; and Fraunhofer Institute for Systems and Innovation Research ISI, Karlsruhe, Germany.

Marco Vivarelli, Università Cattolica del Sacro Cuore, Milan, Italy. initiatives have been mainly driven by concern about the lower productivity of European companies in comparison with their United States competitors. Therefore, European policy makers have advised member countries to strengthen their knowledge base in order to foster productivity and support economic growth. ${ }^{1}$ Yet, despite the substantial shifts in policies during the last two dec-

(C) The Author(s) 2018. Open Access: This article is distributed under the terms of the Creative Commons Attribution 4.0 International License (http://creativecommons.org/licenses/by/4.0/), which permits unrestricted use, distribution, and reproduction in any medium, provided you give appropriate credit to the original author(s) and the source, provide a link to the Creative Commons license, and indicate if changes were made.

1 European Commission: Communication from the Commission to the European Parliament, the Council, the European Economic and Social Committee and the Committee of the Regions, Europe 2020 Flagship Initiative Innovation Union, SEC(2010) 1161, 2010; European Commission: Communication from the Commission to the European Parliament, the Council, the European Economic and Social Committee and the Committee of the Regions, An Integrated Industrial Policy for the Globalisation Era, Putting Competitiveness and Sustainability at Centre Stage, SEC(2010) 1272, SEC(2010) 1276, 2010. 
ades, the productivity gap between European countries and the US has not been significantly reduced. By 2016, the average worker across the $28 \mathrm{EU}$ member states generated $\$ 47.70$ (constant prices, 2010 PPPs) of GDP for every hour worked; in the US the equivalent figure was $\$ 63.30$; for comparison, in 2000 these figures were $\$ 40.10$ and $\$ 50.40$, respectively. ${ }^{2}$ In addition to the EU's widening productivity gap with the US, the entire world economy has entered a phase of low overall productivity growth in the aftermath of the Great Recession. Gordon was one of many prominent economists who wrote about this so-called "secular stagnation", and he largely attributed it to fading technological opportunities. ${ }^{3} \mathrm{We}$ posit that narrowing the EU's productivity gap with respect to the US may be even more problematic in times when declining technological opportunities reduce the overall potential for productivity gains. In addition, the EU industrial structure is much less high-tech intensive than that of the US, and this long-term structural effect can impact productivity. Moreover, the potential capacity of the EU to effectively increase productivity within each industry, compared to the US, is a critical issue. Finally, within the EU, country heterogeneity might be pivotal in determining differences in terms of the productivity consequences of economic cohesion policies. ${ }^{4}$

\section{Secular stagnation: Are there technological origins?}

The past 20 years have seen a remarkable drop in the productivity growth rates for many Western economies. While the empirical observation of low productivity growth rates is well documented, some authors have raised the question of whether simple measurement issues may be the main drivers of these declining growth rates. In particular, one concern is that customary productivity measures do not appropriately reflect the actual productivity gains due to new products. ${ }^{5}$ However, in this respect, Syverson presents evidence indicating that the potential distorting effects of the measurement biases are not large enough to explain the slowdown in productivity growth. ${ }^{6}$ Thus, most researchers today

2 OECD: Productivity statistics database, available at http://www. oecd.org/sdd/productivity-stats/.

3 R.J. Gordon: The Turtle's Progress: Secular Stagnation Meets the Headwinds, in: C. Teulings, R. B ald win (eds.): Secular Stagnation: Facts, Causes and Cures, London 2014, CEPR Press.

4 If resources are directed largely towards the most excellent research proposals, as in Horizon 2020, the result will most likely be a concentration of funds in countries which already perform well. See R. Frietsch, C. Rammer, T. Schubert: Heterogeneity of Innovation Systems in Europe and Horizon 2020, in: Intereconomics, Vol. 50, No. 1, 2015, pp. 9-13.

5 J. Mokyr: Secular stagnation? Not in your life, in: C. Teulings, R. Baldwin, op. cit.

6 C. Syverson: Challenges to Mismeasurement Explanations for the US Productivity Slowdown, NBER Working Paper No. 21974, 2016. agree that the declining productivity growth rates are not illusionary and reflect a real phenomenon.

What are the causes of this declining productivity growth? A widespread view among macroeconomists attributes the causes of stagnation to monetary policies $^{7}$ or abundant social welfare systems ${ }^{8}$. However, a more technology-centred view claims that the slowdown of productivity growth is largely the result of diminishing technological opportunities. ${ }^{9}$ Indeed, this evidence is corroborated by Schubert and Neuhäusler's econometric evidence. ${ }^{10}$ For a panel of 11 OECD countries, they show that the ability to sustain productivity growth through capital investment declined over the period 1993-2011. However, they also provide evidence that the effect of research and development (R\&D) on productivity growth was almost unchanged throughout these years. All in all, given that the effect of embodied technological change has largely come to hold, there is little hope that productivity growth rates might return to "normal" after the economic crisis. Conversely, there is relevant evidence that the productivity-enhancing effects of genuine research activities are not declining.

\section{EU versus US: What are the causes of the transat- lantic productivity gap?}

The literature has pointed to many different causes to explain the origin of the productivity gap between Europe and the US. ${ }^{11}$ Researchers have assigned blame to, among other things, the quality of human capital, the rigidity of European labour markets, the role and diffusion of ICTs, ${ }^{12}$ the importance of new managerial practices and organisational investments, ${ }^{13}$ and embodied technological change. Most of these explanations can

7 L.H. Summers: Demand Side Secular Stagnation, in: American Economic Review, Vol. 105, No. 5, 2015, pp. 60-65.

8 E.L. Glaeser: Secular Joblessness, in: C. Teulings, R. Baldwin, op. cit.

9 B. Eichengreen: Secular Stagnation: The Long View, in: American Economic Review, Vol. 105, No. 5, 2015, pp. 66-70; R.J. Gordon: Secular Stagnation: A Supply-Side View, in: American Economic Review, Vol. 105, No. 5, 2015, pp. 54-59.

10 T. Schubert, P. Neuhäusler: Can Depleting Technological Opportunities Explain the Stagnation of Productivity? Panel Data Evidence for 11 OECD Countries, Studien zum deutschen Innovationssystem, No. 11-2018, Fraunhofer Institute for Systems and Innovation Research ISI, 2018.

11 R. Ortega-Argilés, M. Piva, M. Vivarelli: The Transatlantic Productivity Gap: Is R\&D the Main Culprit?, in: Canadian Journal of Economics, Vol. 47, No. 4, 2014, pp. 1342-1371.

12 G. Bonanno: ICT and R\&D as Inputs or Efficiency Determinants? Analysing Italian Manufacturing Firms (2007-2009), in: Eurasian Business Review, Vol. 6, No. 3, 2016, pp. 189-213.

13 A. Della Malva, E. Santarelli: Intellectual Property Rights, Distance to the Frontier, and R\&D: Evidence from Microdata, in: Eurasian Business Review, Vol. 6, No. 1, 2016, pp. 1-24. 
be related to a revealed technological disadvantage in the EU.

In this regard, both at the aggregate and the microeconomic level, R\&D expenditures can be considered a good proxy of technological investment. Therefore, the gap in corporate R\&D investment can be seen as one of the main culprits of the European lag in terms of productivity growth in comparison with the US. ${ }^{14}$ Indeed, in the last decade, corporate business expenditure on R\&D in the EU has remained almost constant at approximately $1.2 \%$ of GDP. Meanwhile, in the US, this figure has floated between $1.7 \%$ and $2.0 \%$.

Some scholars have argued that the lower European $R \& D$ expenditure is mainly due to a structural composition effect, which appears because the R\&D-intensive manufacturing and R\&D-intensive service sectors are under-represented in the European economy in comparison to the US. ${ }^{15}$

Other authors have stressed the existence of an intrinsic effect, pointing out that European firms have a general difficulty in achieving productivity gains from their R\&D investments. ${ }^{16}$ According to this view, EU firms within each industrial sector are characterised by a lower R\&D intensity in comparison with their US counterparts. In addition, Ortega-Argilés et al. argue that EU companies have a lower capacity for translating $R \& D$ investments into productivity gains than US firms do. ${ }^{17}$

\section{R\&D champions in Europe and the US: Is there a persistent productivity gap?}

Our recent empirical exercise on top R\&D investors suggests that the issue is not just the amount of money spent on R\&D. ${ }^{18}$ Indeed, EU firms are also less successful in translating R\&D investments into productivity

14 M. O'Mahony, B. van Ark (eds.): EU Productivity and Competitiveness: An Industry Perspective, Can Europe Resume the Catching-up Process?, European Commission, Luxembourg 2003, Office for Official Publications of the European Communities; O. Blan ch a rd: The Economic Future of Europe, in: Journal of Economic Perspectives, Vol. 8, No. 1, 2004, pp. 3-26; M. Rogers: R\&D and Productivity: Using UK Firm-level Data to Inform Policy, in: Empirica, Vol. 37, No. 3, 2010, pp. 329-359.

15 A. Mathieu, B.van Pottelsberghe de la Potterie: A Note on The Drivers of R\&D Intensity, CEPR Discussion Paper No. 6684, 2008; R. Ortega-Argilés, A. Brandsma: EU-US Differences in the Size of R\&D Intensive Firms: Do They Explain the Overall R\&D Intensity Gap?, in: Science and Public Policy, Vol. 37, No. 6, 2010, pp. 429-441.

$16 \mathrm{H}$. Erken, F. van Es: Disentangling the R\&D Shortfall of the EU visà-vis the US, Jena Economic Research Papers No. 2007-107, 2007.

17 See R. Ortega-Argilés et al., op. cit.

18 D. Castellani, M. Piva, T. Schubert, M. Vivarelli: The Productivity Impact of R\&D Investment: A Comparison between the EU and the US, IZA Discussion Papers No. 9937, 2016. gains, receiving a smaller return on their investments than US businesses.

We use microdata on the top 1112 R\&D-spending companies in the EU (504) and the US (608), in both manufacturing and services, between 2004 and 2012. ${ }^{19}$ Descriptive statistics show that, on average, R\&D intensity and productivity are lower in EU companies than in US firms. Moreover, as expected, they are larger in hightech industries than in middle- and low-tech ones. In our panel data analysis, we estimate each company's productivity as a function of investments in R\&D, physical capital, company size and industrial characteristics. Our results demonstrate that, for a US company, a ten per cent rise in R\&D intensity yields a $2.7 \%$ increase in productivity. For EU firms, the same investment increases productivity by only approximately one per cent. The gap becomes even more interesting when we disentangle high-tech and middle- and low-tech sectors: for high-tech US companies, a ten per cent rise in R\&D intensity yields a $3.3 \%$ increase in productivity, while for high-tech EU firms, the same investment increases productivity by just $1.2 \%$. When we turn to middle- and low-tech companies, the gap shrinks, although US companies still remain better able to translate R\&D investments into productivity.

We also split the sample into two periods, before and after the global financial crisis. In 2004-08 the return on R\&D spending for EU firms was not quite two-thirds that of their US counterparts, while in 2009-12 it fell to less than half. Therefore, since the economic crisis, it seems EU companies are even less able to translate R\&D investments into productivity gains compared to their US counterparts. However, it is also interesting to underline that EU businesses gain more from capital spending than those in the US: a ten per cent increase in physical capital investments yields a $1.3 \%$ productivity increase in the EU, versus $1.0 \%$ in the US. This result seems to be mainly driven by middle- and low-tech industries, where EU firms gain a $2.2 \%$ productivity gain compared to $1.6 \%$ for US companies. In a sense, productivity growth in European non-high-tech firms is still heavily dependent on investments in physical capital (embodied technological change).

In general, R\&D has potentially a much higher impact on productivity. Across all companies in our sample, a ten per cent increase in $R \& D$ spending leads to a $1.8 \%$

19 The microdata used were provided by the Joint Research CentreInstitute for Prospective Technological Studies of the European Commission. The dataset is mainly based on the EU Industrial R\&D Scoreboard and aggregates information on top R\&D spenders worldwide from 2004 until 2012 
rise in productivity. In comparison, the same increase in physical capital spending boosts productivity by only $1.1 \%$.

On the whole, our results suggest that the transatlantic productivity divide can be explained by:

- a lower level of R\&D investments by EU firms compared to their US counterparts

- a structural composition effect, which seems to be significant both in aggregate and within the high-tech sectors

- the presence of an intrinsic effect, i.e. the generally lower capacity of European firms to translate R\&D investments into productivity gains.

Furthermore, our results show that EU companies have been more affected by the economic crisis with regard to their capacity to translate R\&D investments into productivity. Indeed, the global economic crisis has worsened the productivity gap between the EU and the US.

\section{Challenges for European policy makers}

Turning Europe into the most competitive knowledgebased economy in the world is an ambitious goal. Key economic figures suggest that the EU continues to fall further behind the US - currently the leading economy rather than narrowing the gap. In this paper, we highlight that the EU faces the challenge of reducing its productivity gap in a period characterised by overall low potential for productivity growth. This makes the catching-up process even more difficult.

Focusing on the role played by R\&D in the EU compared to its role in US, our empirical exercise provides robust evidence of both a "quantity effect" (relatively lower R\&D spending by European firms) and a "quality effect" (lower ability of European firms to turn R\&D spending into productivity gains). However, most policy attention has been devoted to the lower levels of R\&D spending rather than the lower capabilities to make efficient use of it; for example, the EU set a target of increasing R\&D investment to three per cent of GDP. Instead of primarily focusing on the symptom (i.e. R\&D investments that are perceived as too (ow), effective policies should take into account the reasons why EU firms obtain less productivity gains from their R\&D investments compared to their US counterparts. To get the most out of R\&D, EU firms need to address the structural problems that reduce their ability to translate investment into productiv- ity gains. The main cause might lie in some combination of available human capital and the organisational/managerial practices adopted (i.e. firms with better-managed R\&D departments might provide relevant incentives and conducive work environments to their researchers, who in turn can be more productive).

In a sense, identifying best practices - embodied by those EU firms most successful at leveraging their R\&D investments - would allow policy to be designed to foster knowledge transfer and learning between firms. Moreover, this would enable EU funding programmes to more effectively promote excellence by favouring such best practices. Indeed, several authors have acknowledged that research and innovation support may become more effective in promoting growth and productivity by taking a more selective approach. ${ }^{20}$ Resources should be concentrated in promising high-tech fields that could potentially initiate and sustain the next phase of high productivity growth.

Although compelling, policies redirecting resources to the most effective uses will unavoidably result in a tendency to concentrate resources in scientific organisations, firms, sectors and, eventually, countries that already perform well in research and innovation. If the major concern to be remedied is the poor average/aggregate performance of the EU in comparison to the US, greater selectiveness in the allocation of support for innovation circumvents the problem of low effectiveness in some parts of Europe rather than addressing it. However, while such a strategy may be effective in increasing the average returns per euro spent, it may come at the high cost of lower European cohesion.

20 R. Veugelers, M. Cincera: How to Turn on the Innovation Growth Machine in Europe, in: Intereconomics, Vol. 50, No. 1, 2015, pp. 4-9. 